\title{
PHENOLIC COMPOUNDS IDENTIFIED IN CHRYSANTEMUM CORONARIUM L. INTRODUCED IN UKRAINIAN POLISSYA
}

\section{Ivashchenko Iryna}

Zhytomyr National Agroecological University, Zhytomyr, Ukraine

\section{ФЕНОЛЬНІ СПОЛУКИ, ІДЕНТИФІКОВАНІ В РОСЛИНАХ СНRYSANTЕMUM CORONARIUM L. ЗА IHТРОДУКЦІї В ПОЛІССІ УКРАЇНИ}

\section{Іващенко Ірина}

Received 24. 6. 2017

Revised 25. 6. 2017

The paper shows the results of chromatographic analysis of phenolic compounds extracted from a valuable vegetable, medicinal, decorative plant - garland chrysanthemum (Chrysantemum coronarium L.), introduced in Ukrainian Polissya. Introduction studies were carried out on experimental plots of Botanical Gardens of Zhytomyr National Agroecological University. Chrysantemum coronarium phenolic compounds were studied by high-performance liquid chromatography (HPLC) method. As a result of the research, 24 compounds of phenolic nature have been detected, from which 13 have been identified: chlorogenic acid, caffeic acid, cafeoylquinic acid, n-coumaroylquinic acid, 3-methylquercetin7-bioside, 3-methylquercetin-3-bioside, rutin, luteolin-7-glycoside, isochlorogenic acid, apigenin-7glucoside, luteolin, 3-methylquercetin, kaemferol. The analysis proves that the dominant components are isochlorogenic acid (35.48\% amount of fenolic compounds), caffeic acid (10.25\%), caffeoylquinic acid $(17.18 \%)$ and luteolin-7-glycoside (7.85\%). The amount of the detected phenolic compounds in air-dry raw material constitutes $2.18 \%$. The research testifies to the fact that garland chrysanthemum contains an important group of biologically active substances (hydroxycinnamic acids and flavonoids) and is a promising plant for further study and application in the food and pharmaceutical industries.

Keywords: Chrysantemum coronarium L.; Asteraceae; phenolic compounds; flavonoids; chromatography; introduction; Ukrainian Polissya

\section{Вступ}

Хризантема увінчана (Chrysantemum coronarium L.) - однорічна трав'яниста рослина родини Asteraceae Dumort., триби Anthemideae. Ботанічні синонімічні назви : Glebionis coronaria L. Cassini ex Spach, Glebionis coronaria var. discolor, Glebionis coronaria var. coronaria, Chrysanthemum roxburghii Desf., Glebionis roxburghii (Desf.) Tzvelev, Xantophtalmum coronarium (L.) P.D. Sell., Matricaria coronaria (L.) Desr. Вона відома як харчова, лікарська, декоративна рослина; містить вітаміни, каротини, мікро- і макроелементи, прості та складні вуглеводи, протеїни, лактони, ефірну олію (Tawaha and Hudaib, 2010; Geest et al., 2016; Wan et al., 2017). Хризантема увінчана - багате джерело фенольних сполук з різноманітною біологічною активністю (Harborne et al., 1970;

\footnotetext{
*Corresponding author: Iryna Ivashchenko, Zhytomyr National Agroecological University, Zhytomyr,
} Ukraine, $\bowtie$ kalateja@ukr.net 
Chuda at al.,1996; Ibrahim et al., 2007; Lai et al., 2007), ïï можливо розглядати як перспективну біологічно активну добавку, що сприятливо впливатиме на організм людини.

Цінність хризантеми увінчаної визначає актуальність досліджень з вивчення компонентного складу фенольних сполук за умов інтродукції в зоні Полісся України.

Метою роботи було вивчення методом ВЕРХ якісного та кількісного вмісту окремих фенольних сполук надземної частини рослин хризантеми увінчаної за інтродукції в Поліссі України для встановлення можливості її використання у харчовій та фармацевтичній промисловості.

\section{Матеріали та методи}

Інтродукційні дослідження проводили на експериментальних ділянках ботанічного саду Житомирського національного агроекологічного університету. Насіннєвий матеріал Chrysantemum coronarium отримано із Національного ботанічного саду ім. М. М. Гришка НАН України. Сировину збирали у фазу цвітіння рослин.

Фенольні сполуки Chrysantemum coronarium вивчали на високоефективному рідинному хроматографі Prominens 20 фірми «Shimadzu» (Японія). Комплектація хроматографа: мікроплунжерна насосна станція LC - 20 AD з модулем чотириканального градієнта низького тиску LPG і проточним вакуумним дегазатором DGU - 20 А3; система автоматичного введення проби SIL - 20A; термостат колонок CTO-20A; спектрофотометричний діодно-матричний детектор SPD-M20A 3 аналітичною проточною мікрокюветою. Колонка хроматографічна: Supelco Discovery HS C18 розміром $150 \times 2,1$ мм, заповнена зворотнофазним сорбентом із зернінням Змкм.

Екстракти рослин для хроматографічних досліджень отримували настоюванням повітряносухої сировини у 50\%-му метанолі протягом 7 діб (1:4).

Розділення здійснювали в градієнтному режимі. Розчинниками слугували: розчин А - 0,5 \%-й розчин перхлоратної кислоти (рH 1,5) у дистильованій воді; розчин В - суміш 40 \% метанолу кваліфікації для BEPX (Merck), 40 \% ацетонітрилу кваліфікації для BEPX (Lab-Scan), 20 \% розчину А. Швидкість потоку розчинників становила 0,2 мл/хв. Об'єм проби для введення - 1мкл. Детектування здійснювали за 280, 310, 330, 360, 525 нм одночасно.

Спектральні характеристики реєстрували за даними сканування в момент виходу піка в діапазоні довжин хвиль 235 - 550 нм. Піки ідентифікували методом зіставлення із стандартними зразками за часом виходу і спектром, а також за методом добавок. Належність до тієї чи іншої групи природних сполук визначали за подібністю спектральних характеристик. Градуювання здійснювали за розчинами стандартних зразків відомої концентрації. Концентрації в досліджуваних пробах розраховували за площею піків із використанням програмного забезпечення LC Solution (Shimadzu).

\section{Результати та їх обговорення}

В результаті проведеного хроматографічного аналізу в рослинах хризантеми увінчаної виявили 24 сполуки фенольної природи, з яких ідентифікували хлорогенову, ізохлорогенову, кавову, кофеїлхінну, n-кумароїлхінну кислоти та флавоноїди: 3-метилкверцетин-7-біозид, 3-метилкверцетин-3-біозид, рутин, лютеолін-7-глікозид, апігенін-7-глікозид, лютеолін, 3-метилкверцетин, кемпферол (рис. 1, табл. 1). Домінуючими компонентами виявились ізохлорогенова кислота (35,48 \%), кавова кислота (10,25\%), кофеїлхінна кислота $(17,18 \%)$ та лютеолін-7-глікозид (7,85\%). Вміст виявлених фенольних сполук у повітряно-сухій сировині становив 2,18\%.

Отримані нами результати узгоджуються з даними зарубіжних дослідників, які виявили в рослинах хризантеми увінчаної хлорогенову кислоту, ізомери дикофеїлхінної кислоти, рутин, лютеолін, лютеолін-7-О-глікозид, мірицитин-3-О-галактозид, трицин та 4-сукциніл-3,5- 
дикофеїлхінну кислоту (Lai et al., 2007; Hosni et al., 2013). Проте, мірицитин-3-О-галактозид, трицин та 4-сукциніл-3,5-дикофеїлхінна кислота нами не ідентифіковані.

Таблиця 1 Компонентнй склад та кількісний вміст фенольних сполук надземної частини рослин Chrysantemum coronarium L., ідентифікованих методом BEPX

Table 1 Composition and quantitative content of phenolic compounds in Chrysantemum coronarium L. areal parts, identified by HPLC-method

\begin{tabular}{|c|c|c|c|}
\hline $\begin{array}{c}\text { Час } \\
\text { утримання, Хв. }\end{array}$ & Сполука & $\begin{array}{l}\text { Вміст у повітряно- } \\
\text { сухій сировині, мг/г }\end{array}$ & $\begin{array}{c}\text { Частка суми виявлених } \\
\text { фенольних сполук, \% }\end{array}$ \\
\hline 17,16 & хлорогенова кислота & $0,10 \pm 0,007$ & 0,48 \\
\hline 21,31 & кавова кислота & $2,23 \pm 0,003$ & 10,25 \\
\hline 22,67 & кофеїлхінна кислота & $0,08 \pm 0,002$ & 0,37 \\
\hline 23,77 & n-кумароїлхінна кислота & $0,09 \pm 0,001$ & 0,39 \\
\hline 26,61 & - & $0,09 \pm 0,003$ & 0,04 \\
\hline 28,65 & 3-метилкверцетин-7-біозид & $0,77 \pm 0,016$ & 3,55 \\
\hline 30,91 & 3-метилкверцетин-3-біозид & $0,04 \pm 0,002$ & 0,19 \\
\hline 31,85 & Рутин & $0,39 \pm 0,003$ & 1,77 \\
\hline 32,33 & лютеолін-7-глікозид & $1,71 \pm 0,014$ & 7,85 \\
\hline 34,07 & ізохлорогенова кислота & $0,26 \pm 0,025$ & 35,48 \\
\hline 34,6 & ізохлорогенова кислота & $6,31 \pm 0,018$ & - \\
\hline 37,03 & ізохлорогенова кислота & $1,16 \pm 0,009$ & - \\
\hline 37,87 & апігенін-7-глікозид & $0,09 \pm 0,002$ & 0,44 \\
\hline 38.99 & кофеїлхінна кислота & $3,66 \pm 0,017$ & 16,81 \\
\hline 43,54 & - & $0,09 \pm 0,004$ & 0,04 \\
\hline 44,38 & лютеолін & $1,42 \pm 0,017$ & 6,54 \\
\hline 45,63 & 3-метилкверцетин & $0,17 \pm 0,004$ & 0,78 \\
\hline 49,34 & - & $0,31 \pm 0,005$ & 0,14 \\
\hline 52,92 & - & $0,52 \pm 0,006$ & 0,24 \\
\hline 54,33 & кемпферол & $0,18 \pm 0,004$ & 0,25 \\
\hline 56,28 & - & $0,67 \pm 0,005$ & 0,31 \\
\hline 56,88 & - & $0,62 \pm 0,009$ & 0,28 \\
\hline 57,55 & - & $0,62 \pm 0,006$ & 0,28 \\
\hline 58,68 & - & $0,17 \pm 0,003$ & 0,08 \\
\hline
\end{tabular}




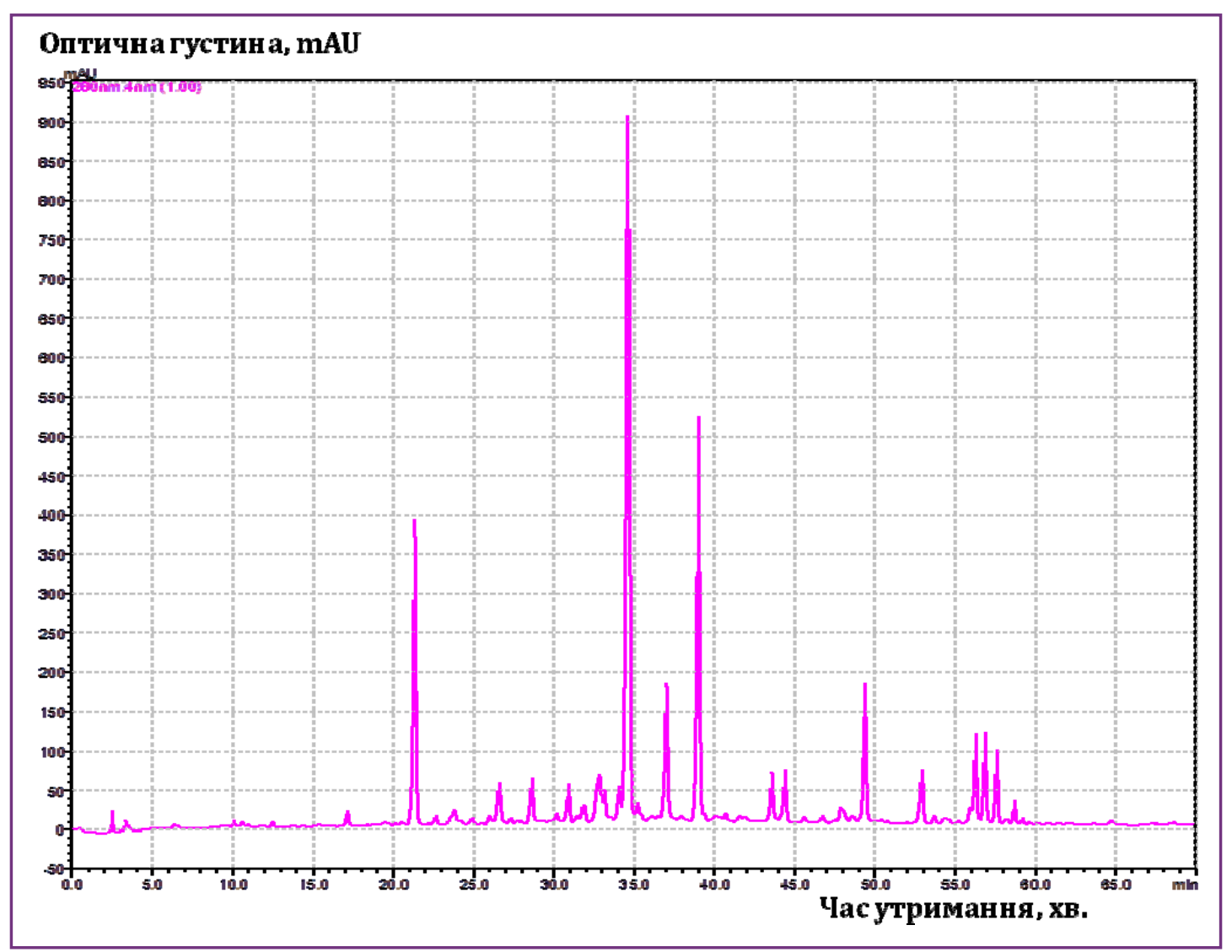

Рисунок 1 Хроматограма фенольних сполук екстракту Chrysantemum coronarium L.

Figure 1 Chromatogram of phenolic compounds obtained from Chrysantemum coronarium L. extract

Відомо, що фенольні сполуки проявляють захисну роль в канцерогенезі, запаленні, атеросклерозі, тромбозі, а також мають високу антиоксидантну активність, антимікробні властивості (Nishiumi et al., 2011; Valdes et al., 2015). Згідно літературних джерел, рослини хризантеми овочевої характеризуються високим показником антиоксидатної активності та виявляють антимікробні властивості, що, можливо, пов'язано із вмістом фенольних сполук (Chuda, 1996; Lograda et al., 2013; Ivashchenko, 2017).

\section{Висновки}

Методом ВЕРХ в рослинах хризантеми увінчаної виявили 24 сполуки фенольної природи, ідентифікували хлорогенову, ізохлорогенову, кавову, кофеїлхінну, n-кумароїлхінну кислоти та флавоноїди: 3-метилкверцетин-7-біозид, 3-метилкверцетин-3-біозид, рутин, лютеолін7-глікозид, апігенін-7-глікозид, лютеолін, 3-метилкверцетин, кемпферол. Вміст виявлених фенольних сполук у повітряно-сухій сировині становив 2,18\%.

Основні компоненти, \%: ізохлорогенова кислота $(35,48)$, кавова кислота $(10,25)$, кофеїлхінна кислота $(17,18)$ та лютеолін-7-глікозид $(7,85)$.

Результати досліджень свідчать, що хризантема увінчана містить важливу групу біологічно активних речовин - гідрксикоричних кислот та флавоноїдів і $\epsilon$ перспективною культурою для подальшого вивчення і застосування у харчовій промисловості та фармації. 


\section{Література}

Chuda, Y., Ono, H., Ohnishi-Kameyama, M., Nagata, T., Tsushida, T. 1996. Structural identification of two antioxidant quinic acid derivatives from garland (Chrysanthemum coronarium L.). Journal of Agricultural and Food Chemistry, vol. 44, p. 2037-2039. DOI: 10.1021/jf960182

Geest, G., Choi, Y. H., Arens, P., Post, A., Liu, Y., Meeteren, U. 2016. Genotypic differences in metabolomic changes during storage induced-degreening of chrysanthemum disk florets. Postharvest Biology and Technology, vol. 115, p. 48-59. DOI:10.1016/j.postharvbio.2015.12.008

Harborne, J. B., Heywood, V. H., Saleh, N. A. M. 1970. Chemosystematics of the composiate: Flavonoid patterns in the Chrysanthemum complex of the tribe Anthemideae. Phytochemistry, vol. 9 (9), p. $2011-$ 2017. DOI:10.1016/S0031-9422(00)85354-6

Hosni, K., Hassen, I., Sebei, H., Casabianca, H. 2013. Secondary metabolites from Chrysanthemum coronarium (Garland) flowerheads: chemical composition and biological activities. Industrial Crops and Products, vol. 44, p. 263-271. DOI: 10.1016/j.indcrop.2012.11.033.

Ibrahim, L. F., El-Senousy, W. M. \& Hawas, U. W. 2007. NMR spectral analysis of flavonoids from Chrysanthemum coronarium. Chemistry of Natural Compounds, vol. 43, no. 6, p. 659-662. DOI:10.1007/ s10600-007-0222-y

Ivashchenko, I. 2017. Chemical composition of essential oil and antimicrobial properties of Chrysantemum coronarium (Asteraceae). Biosystems Diversity, vol. 25, no. 2, p. 119-123. DOI: 10.15421/011709.

Lai, J.-P., Lim, Y. H., Su, J., Shen, H.-M., Ong, C. N. 2007. Identification and characterization of major flavonoids and caffeoylquinic acids in three Compositae plants by LC/DAD-APCI/MS. Journal of Chromatography $B$, vol. 848, no. 2, p. 215-225. DOI: 10.1016/j. jchromb. 2006.10.028

Lograda, T., Ramdani, M., Chalard, P., G. Figueredo, G., Silini, H., Kenoufi, M. 2013. Chemical composition, antibacterial activity and chromosome number of Algerian populations of two chrysanthemum species. Journal of Applied Pharmaceutical Science, vol. 3 (8 Suppl 1), p. 6-11. DOI: 10.7324/JAPS.2013.38.S2

Nishiumi, S., Miyamoto, S., Kawabata, K., Ohnishi, H., Mukai, R., Murakami, A., Ashida, H., Terao, J. 2011. Dietary flavonoids as cancer-preventive and therapeutic biofactors. Front Biosci. (Schol. Ed.), vol. 3, p. 1332-1336.

Tawaha, K., Hudaib, M. 2010. Volatile oil profiles of the aerial parts of Jordanian garland, Chrysanthemum coronarium. Pharmaceutical Biology, v. 48, no. 10, p. 1108-1114. DOI: 10.3109/13880200903505641

Valdés, L., Cuervo, A., Salazar, N., Ruas-Madiedo, P., Gueimonde, M., González, S. 2015. The relationship between phenolic compounds from diet and microbiota: impact on human health. Food Funct., vol. 6, no. 8, p. 2424-2439.

Wan, C., Li, S., Liu, L., Chen, C., and Fan, S. 2017. Caffeoylquinic Acids from the Aerial Parts of Chrysanthemum coronarium L. Plants, vol. 6, no. 10, p. 1-7. DOI:10.3390/plants6010010. 